\title{
The Risk Factors for Delirium in Patients with Stroke in Palliative Care
}

\section{Palyatif Bakımda İnmeli Hastalarda Deliryum İçin Risk Faktörleri}

\author{
(Eülhan Sarıçam', DOrkun Sarıçam² \\ 'Pursaklar State Hospital, Department of Neurology Clinic, Ankara, Turkey \\ 2Pursaklar State Hospital, Department of Internal Medicine Clinic, Ankara, Turkey
}

\begin{abstract}
Aim: Post-stroke delirium is an acute neuropsychiatric syndrome that increases the distress of patients and family members and leads to long-term results, especially in older age. In this study, we aimed to investigate the risk factors for delirium in patients followed-up in palliative care with the diagnosis of stroke.

Material and Method: This retrospective study included 161 patients followed-up in the palliative care ward with the diagnosis of stroke. Patients diagnosed with stroke were grouped as ischemic stroke (IS), hemorrhagic stroke (HS) and subarachnoid hemorrhage (SAH). The age, gender, Glasgow coma scale (GCS), percutaneous endoscopic gastrostomy (PEG) status, presence of infection, electrolyte values, length of hospitalization, discharge conditions and comorbid diseases of the patients included in the study were evaluated.
\end{abstract}

Results: The average age of the patients was $70.49 \pm 15.269$ years, the length of hospitalization was $46.6 \pm 16.11$ days, and 35 (21.1\%) patients had been diagnosed with delirium. In patients who developed delirium, the ages were significantly lower, the infection rates were significantly higher, and the length of hospitalization was significantly longer $(p=0.046, p<0.001, p=0.003)$. While the proportion of patients with a PEG was significantly lower, the rate use of anticholinergics, narcotic analgesics, antiepileptics and antipsychotics was significantly higher in patients who had developed delirium.

Conclusion: We think that determining and managing the risk factors for delirium development in stroke patients followed-up in palliative care will decrease the morbidity and improve the quality of life of the patients and that further studies on this topic are needed.

Keyword: Palliative care, stroke, delirium, length of hospitalization
Öz

Amaç: İnme sonrası deliryum, hastaların ve aile üyelerinin sıkıntısını arttıran ve özellikle ileri yaşlarda uzun süreli sonuçlara yol açan akut nöropsikiyatrik bir sendromdur. Biz bu çalışmada palyatif bakımda stroke tanısı ile izlenen hastalarda deliryum için risk faktörlerini araştırmayı amaçladık.

Gereç ve Yöntem: Bu retrospektif çalışmaya palyatif bakım servisinde stroke tanısı ile izlenen 161 hasta dahil edildi. İnme tanılı hastalar iskemik inme (IS), hemorajik inme (HS) ve subaraknoid kanama (SAK) olarak gruplandırıldı. Çalışmaya alınan hastaların yaşları, cinsiyetleri, glaskow koma skalaları (GKS), perkütan endoskopik gastrostomi (PEG), enfeksiyon varlığı, elektrolit değerleri, ilaç kullanımı, yatış süreleri, çıkış durumları ve komorbid hastalıkları değerlendirildi.

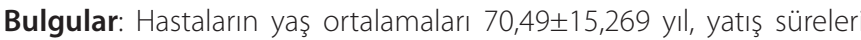
46.6 \pm 16.11 gündü ve 35 (\%21.1) hasta deliryum tanısı aldı. Deliryum gelişen hastaların yaşları anlamlı derecede daha düşük, enfeksiyon oranları anlamlı derecede fazla ve yatış süreleri anlamlı derecede uzundu ( $p=0.046, p<0.001, p=0.003$ ). Deliryum gelişen hastalarda PEG olanların oranı anlamlı derecede azken, antikolinerjik, narkotik analjezik, antiepileptik ve antipiskotik kullananların oranı anlamlı derecede daha fazlaydı.

Sonuçlar: Palyatif bakımda izlenen inmeli hastalarda deliryum gelişimindeki risk faktörlerinin belirlenip iyi yönetilmesinin, hastaların morbiditelerini azaltıp, yaşam kalitelerini iyileştireceğini ve bu konuda daha fazla çalışmaya ihtiyaç olduğunu düşünüyoruz

Anahtar Kelime: Palyatif bakım, stroke, deliryum, hastanede yatış süresi

Corresponding (iletişim): Gülhan Sarıçam, Department of Neurology Clinic, Ankara Pursaklar State Hospital, Mimar Sinan Mah. Çağatay Sok. No:39 Ankara, Turkey

E-mail (E-posta): gulhansar01@hotmail.com

Received (Geliş Tarihi): 09.07.2021 Accepted (Kabul Tarihi): 04.11.2021 


\section{INTRODUCTION}

Delirium is defined as a disorder of awareness and cognition (mostly attention and memory); it develops within hours or days, cannot be explained by other cognitive disorders such as dementia, and is a direct result of a physical condition or medication. ${ }^{[1]}$ Unlike many serious diseases, stroke is a sudden and unexpected condition, and it is a leading cause of severe long-term disability. ${ }^{[2]}$ Post-stroke delirium is an acute neuropsychiatric syndrome that increases the distress of patients and family members and leads to long-term results, especially in older age..$^{[3,4]}$

The palliative care needs of patients after stroke are extensive and evident. ${ }^{[5]}$ Patients are directed to palliative care after stroke for end-of-life decisions rather than symptom management. ${ }^{[6,7]}$ Stroke patients seen by palliative care specialists are more functionally impaired, less likely to possess decision-making capacity and more likely to die in the hospital. ${ }^{[6]}$ Stroke itself is a known predisposing factor for delirium. ${ }^{[3]}$ Studies have reported that the frequency of delirium varies between $12 \%$ and $43 \%$ in patients with ischemic stroke (IS) and hemorrhagic stroke (HS). ${ }^{[8,9]}$ It has been reported that the prevalence of delirium is $13-42 \%$ in patients receiving inpatient palliative care, and that it increases to $88 \%$ at the end of life (weeks to hours before death). However, we found no literature on the delirium rates of stroke patients in palliative care. ${ }^{[10]}$

The pathophysiology of delirium is multifactorial and not fully understood. There are some risk factors for delirium such as advanced age, male gender, an underlying cognitive disorder, medication use, electrolyte disorders, infection, fever, orthopedic and cardiovascular surgeries. ${ }^{[1]]}$ In this study, we aimed to investigate the risk factors for delirium in patients diagnosed with stroke followed-up in palliative care.

\section{MATERIAL AND METHOD}

The retrospective study was approved by Dr. Abdurrahman Yurtaslan Ankara Oncology Training and Research Hospital Ethics Committee (Date: 08.07.2020, Decision No:202007/682). All procedures were applied per the principles of the Declaration of Helsinki. The files of 161 patients who had been followed-up with the diagnosis of stroke in the palliative care center (PCC) of our hospital between 20152020 were reviewed retrospectively. Patients diagnosed with stroke were classified as ischemic stroke (IS), hemorrhagic stroke (HS) and subarachnoid hemorrhage (SAH). The age, gender, Glasgow coma scale (GCS), percutaneous endoscopic gastrostomy (PEG) status, presence of infection, electrolyte values, length of hospitalization, discharge conditions, and comorbid diseases of the patients included in the study were evaluated. Comorbid diseases were classified as dementia, heart disease (HD), hypertension (HT) and diabetes mellitus (DM).
The study collected the data from the medical records written by psychiatrists who had evaluated the patients. The delirium diagnosis was determined using the "Confusion Assessment Method" (CAM) survey. ${ }^{[12]}$ The presence of infection was defined by laboratory tests, identification of pathogens in a bacterial culture or empirical use of antibiotics. The kidney function was evaluated by calculating the blood urea nitrogen (BUN) and plasma creatinine levels and the liver functions by blood aspartate transaminase (AST) and alanine transaminase (ALT) levels, as well as plasma albumin levels. Electrolyte imbalance was assessed by determining the levels of sodium and potassium. The medications used by patients were classified as antipsychotics, anticholinergics, antiepileptics and narcotic analgesics.

\section{Statistical Analyses}

The study data comprised 161 individuals. The analyses were performed using the IBM SPSS statistics 23 software bundle. While evaluating the study data, number were given for the categorical variables and descriptive statistics (mean, standard deviation, median, minimum, maximum) were given for the numerical variables. The normality assumptions of the numerical variables were examined using the Kolmogorov Smirnov normality test and it was observed that the variables were not normally distributed. Therefore, non-parametric statistical methods were used in the study. The differences between the two independent groups were examined using the Mann Whitney U Analysis. The relationship between two independent categorical variables was interpreted using the Chi-Square analysis. The statistical significance level in the analysis was accepted as 0.05 .

\section{RESULTS}

A total of 161 stroke patients, 74 of which (46\%) were female and 87 (54\%) were male, were included in the study. The mean age of the patients was $70.49 \pm 15.269$ years, and $97(60.2 \%)$ patients had been diagnosed as IS, 32 (19.9\%) patients had been diagnosed as HS and 32 (19.9\%) patients had been diagnosed as $\mathrm{SAH}$. The average length of hospitalization of the patients was $46.6 \pm 16.11$ days and the GCS was $10.6 \pm 2.17$. Among these patients, 92.5\% had HT, 50.3\% had HD, 27.3\% had DM and $14.9 \%$ had dementia as comorbidity. Thirty-five (21.1\%) patients had been diagnosed with delirium (Table 1).

There were significant differences between the patients with and without delirium in terms of age, infection status, and the length of hospitalization. Accordingly, the ages of the patients who had developed delirium were significantly lower than those who had not $(p=0.046)$. The length of hospitalization of patients who had developed delirium was significantly longer and the rate of infection was significantly higher than patients who had not developed delirium $(p=0.003, p<0.001)$ (Table 2). 


\section{Table 1. Demographic characteristics of stroke patients}

\begin{tabular}{|c|c|c|}
\hline$(n=161)$ & Mean & Standard Deviation \\
\hline Age & 70.49 & 15.269 \\
\hline Length of hospitalization & 46.62 & 16.119 \\
\hline \multirow[t]{2}{*}{ GCS } & 10.68 & 2.172 \\
\hline & $\mathbf{n}$ & $\%$ \\
\hline \multicolumn{3}{|l|}{ Gender } \\
\hline Female & 74 & 46.0 \\
\hline Male & 87 & 54.0 \\
\hline \multicolumn{3}{|l|}{ Diagnosis } \\
\hline IS & 97 & 60.2 \\
\hline $\mathrm{HS}$ & 32 & 19.9 \\
\hline SAH & 32 & 19.9 \\
\hline \multicolumn{3}{|l|}{ Dementia } \\
\hline Present & 24 & 14.9 \\
\hline Absent & 137 & 85.1 \\
\hline \multicolumn{3}{|l|}{ DM } \\
\hline Present & 44 & 27.3 \\
\hline Absent & 117 & 72.7 \\
\hline \multicolumn{3}{|l|}{ HT } \\
\hline Present & 149 & 92.5 \\
\hline Absent & 12 & 7.5 \\
\hline \multicolumn{3}{|l|}{ HD } \\
\hline Present & 81 & 50.3 \\
\hline Absent & 80 & 49.7 \\
\hline \multicolumn{3}{|l|}{ Delirium } \\
\hline Present & 35 & 21.7 \\
\hline Absent & 126 & 78.3 \\
\hline \multicolumn{3}{|l|}{ Discharge Condition } \\
\hline Exitus & 29 & 18.0 \\
\hline Alive & 132 & 82.0 \\
\hline
\end{tabular}

There were significant differences between the patients with and without delirium in levels of glucose, creatinine, sodium, ALT, and albumin. There was a statistically significant relationship between the development of delirium and the PEG status. $(p=0.015)$ While the glucose, creatinine and ALT levels of patients who had developed delirium were significantly higher than those without delirium, their $\mathrm{Na}$ and albumin levels were significantly lower. The proportion of patients with PEG was significantly lower among patients with delirium ( $p=0.0015)$ (Table 3).

There were significant differences between the patients with and without delirium the use of anticholinergics, narcotic analgesics, antiepileptics, and antipsychotics. Accordingly, the rate of anticholinergic, narcotic analgesic, antiepileptic and antipsychotic users among patients with delirium was significantly higher than those without delirium ( $p=0.003$, $p<0.001, p=0.004, p<0.001$ ) (Table 4).
Table 2. Evaluation of the relationship between the delirium status and the variables

\begin{tabular}{|c|c|c|c|c|c|c|}
\hline & \multicolumn{4}{|c|}{ Delirium } & \multirow{3}{*}{$\begin{array}{l}\text { Chi- } \\
\text { square }\end{array}$} & \multirow{3}{*}{$\mathbf{p}$} \\
\hline & \multicolumn{2}{|c|}{ Present } & \multicolumn{2}{|c|}{ Absent } & & \\
\hline & $\mathbf{n}$ & $\%$ & $\mathbf{n}$ & $\%$ & & \\
\hline \multicolumn{7}{|l|}{ Gender } \\
\hline Female & 16 & 45.7 & 58 & 46.0 & \multirow[t]{2}{*}{0.001} & \multirow[t]{2}{*}{0.973} \\
\hline Male & 19 & 54.3 & 68 & 54.0 & & \\
\hline \multicolumn{7}{|l|}{ Diagnosis } \\
\hline IS & 17 & 48.6 & 80 & 63.5 & \multirow{3}{*}{5.852} & \multirow{3}{*}{0.054} \\
\hline $\mathrm{HS}$ & 6 & 17.1 & 26 & 20.6 & & \\
\hline $\mathrm{SAH}$ & 12 & 34.3 & 20 & 15.9 & & \\
\hline \multicolumn{7}{|l|}{ Dementia } \\
\hline Present & 8 & 22.9 & 16 & 12.7 & \multirow[t]{2}{*}{2.228} & \multirow[t]{2}{*}{0.135} \\
\hline Absent & 27 & 77.1 & 110 & 87.3 & & \\
\hline \multicolumn{7}{|l|}{ DM } \\
\hline Present & 9 & 25.7 & 35 & 27.8 & \multirow[t]{2}{*}{0.059} & \multirow[t]{2}{*}{0.809} \\
\hline Absent & 26 & 74.3 & 91 & 72.2 & & \\
\hline \multicolumn{7}{|l|}{ HT } \\
\hline Present & 33 & 94.3 & 116 & 92.1 & \multirow[t]{2}{*}{0.006} & \multirow[t]{2}{*}{1.000} \\
\hline Absent & 2 & 5.7 & 10 & 7.9 & & \\
\hline \multicolumn{7}{|l|}{ HD } \\
\hline Present & 13 & 37.1 & 68 & 54.0 & \multirow[t]{2}{*}{3.102} & \multirow[t]{2}{*}{0.078} \\
\hline Absent & 22 & 62.9 & 58 & 46.0 & & \\
\hline \multicolumn{7}{|l|}{ Infection } \\
\hline Present & 22 & 62.9 & 29 & 23.0 & \multirow[t]{2}{*}{20.089} & \multirow[t]{2}{*}{0.000} \\
\hline Absent & 13 & 37.1 & 97 & 77.0 & & \\
\hline \multicolumn{7}{|c|}{ Discharge Condition } \\
\hline Exitus & 7 & 20.0 & 22 & 17.5 & \multirow[t]{2}{*}{0.120} & \multirow[t]{2}{*}{0.729} \\
\hline Alive & 28 & 80.0 & 104 & 82.5 & & \\
\hline & Median & Min.-Max. & Median & Min-Max. & $\mathbf{z}$ & $\mathbf{p}$ \\
\hline Age & 68.0 & $44-90$ & 76.0 & $20-94$ & -1.995 & 0.046 \\
\hline GCS & 10.0 & $7-15$ & 10.0 & $7-15$ & -0.462 & 0.644 \\
\hline $\begin{array}{l}\text { Length of } \\
\text { hospitalization }\end{array}$ & 47.0 & $9-257$ & 31.0 & $7-257$ & -2.953 & 0.003 \\
\hline
\end{tabular}

Table 3. Evaluation of the relationship between the delirium status and laboratory parameters and PEG

\begin{tabular}{|c|c|c|c|c|c|c|}
\hline & \multicolumn{4}{|c|}{ Delirium } & \multirow{3}{*}{$\mathbf{Z}$} & \multirow{3}{*}{$\mathbf{p}$} \\
\hline & \multicolumn{2}{|c|}{ Present } & \multicolumn{2}{|c|}{ Absent } & & \\
\hline & Median & $\begin{array}{l}\text { Min.- } \\
\text { Max. }\end{array}$ & Median & $\begin{array}{l}\text { Min.- } \\
\text { Max. }\end{array}$ & & \\
\hline Glucose & 119.0 & $79-189$ & 98.5 & $74-200$ & -2.989 & 0.003 \\
\hline Urea & 23.0 & $0.6-64$ & 18.0 & $0.2-62$ & -1.929 & 0.054 \\
\hline Creatinine & 0.6 & $0.2-4.1$ & 0.5 & $0.1-3.5$ & -2.869 & 0.004 \\
\hline K & 3.9 & $2.9-4.9$ & 3.9 & $2.3-5.4$ & -1.064 & 0.287 \\
\hline $\mathrm{Na}$ & 134.0 & $128-143$ & 138.0 & $130-147$ & -3.777 & 0.000 \\
\hline AST & 21.0 & $9-66$ & 18.0 & $5-44$ & -1.001 & 0.317 \\
\hline ALT & 20.0 & $6-71$ & 15.0 & $2-73$ & -2.751 & 0.006 \\
\hline \multirow[t]{2}{*}{ Albumin } & 2.5 & $1.6-3.9$ & 2.8 & $1.6-4.1$ & -3.561 & 0.000 \\
\hline & $\mathbf{n}$ & $\%$ & $\mathbf{n}$ & $\%$ & $\begin{array}{c}\text { Chi- } \\
\text { square }\end{array}$ & $\mathbf{p}$ \\
\hline \multicolumn{7}{|l|}{ PEG } \\
\hline Present & 20 & 57.1 & 98 & 77.8 & 5.958 & 0.015 \\
\hline Absent & 15 & 42.9 & 28 & 22.2 & & \\
\hline
\end{tabular}

PEG Percutaneous Endoscopic Gastrostomy, K: Potassium, Na: Sodium, ALT: Alanine aminotransferase, AST: Aspartate aminotransferase 


\begin{tabular}{|c|c|c|c|c|c|c|}
\hline & \multicolumn{4}{|c|}{ Delirium } & \multirow{3}{*}{$\begin{array}{l}\text { Chi- } \\
\text { square }\end{array}$} & \multirow{3}{*}{$\mathbf{p}$} \\
\hline & \multicolumn{2}{|c|}{ Present } & \multicolumn{2}{|c|}{ Absent } & & \\
\hline & $\mathbf{n}$ & $\%$ & $\mathbf{n}$ & $\%$ & & \\
\hline \multicolumn{7}{|c|}{ Anticholinergic } \\
\hline Present & 11 & 31.4 & 14 & 11.1 & 8.620 & 0.003 \\
\hline Absent & 24 & 68.6 & 112 & 88.9 & & \\
\hline \multicolumn{7}{|c|}{ Narcotic Analgesic } \\
\hline Present & 17 & 48.6 & 5 & 4.0 & 46.191 & 0.000 \\
\hline Absent & 18 & 51.4 & 121 & 96.0 & & \\
\hline \multicolumn{7}{|c|}{ Antiepileptic } \\
\hline Present & 21 & 60.0 & 42 & 33.3 & 8.178 & 0.004 \\
\hline Absent & 14 & 40.0 & 84 & 66.7 & & \\
\hline \multicolumn{7}{|c|}{ Antipsychotic } \\
\hline Present & 13 & 37.1 & 13 & 10.3 & 14.556 & 0.000 \\
\hline Absent & 22 & 62.9 & 113 & 89.7 & & \\
\hline
\end{tabular}

\section{DISCUSSION}

Delirium is a temporary neurocognitive disorder characterized by cognitive, psychomotor and behavioral symptoms, and it is a common complication after stroke. ${ }^{[13]}$ In our study, we detected delirium in 35 (21.1\%) of stroke patients followed in palliative care. In their study, Farhaan S. Vahidy and colleagues found that the rate of delirium was higher in HS patients (ICH: $10.0 \%, \mathrm{SAH}: 9.8 \%)$ than in IS patients (7.0\%). ${ }^{[14]}$ In our study, the delirium rates in palliative care were higher in $\mathrm{HS}$ patients (HS: $18.5 \%, \mathrm{SAH}: 37.5 \%)$ than in IS patients (17.5\%), but this did not create a statistically significant difference. $(p=0.054)$

Previous studies have shown that advanced age, infection and dementia pose a high risk of developing delirium after a stroke. ${ }^{[15]}$ In the patients we followed in palliative care who developed delirium after a stroke, the infection rate was significantly high, and their average age was significantly low. Advanced age $(\geq 65)$ has been shown as a risk for delirium in many studies. ${ }^{[14]}$ Caeiro et al. ${ }^{[16]}$ identified the average age as 63.6 in stroke patients who developed delirium. In our study, although the mean age of patients with delirium was 66.6, it was considered to be low when compared with patients without delirium. We have thought that admission of some poststroke patients to the palliative care in the advance stage of the disease might be a factor acting on the difference in the mean age.

It was previously shown that the duration of hospitalization and mortality increased in patients who developed delirium after a stroke and that delirium negatively affected the prognosis. ${ }^{[17]}$ In our study, the length of hospitalization was significantly longer in patients with stroke under our followup in palliative care, but there was no significant difference in the exitus rates. Similarly, Nydahl et al. ${ }^{[18]}$ showed that complication rates increased, but mortality did not increase in patients with delirium that they followed in the primary stroke unit.
In their hospital-based study, Khurana and colleagues ${ }^{[19]}$ showed that the second major risk factor for delirium after sepsis and infection was metabolic abnormalities. The glucose, creatinine and ALT levels were significantly higher, and the $\mathrm{Na}$ and albumin levels were significantly lower in patients with stroke who developed delirium, whom we followed in palliative care. In their study, Kotfis et al. ${ }^{[20]}$ found that acute renal failure and impaired glucose tolerance posed a high risk of delirium development after a stroke, and that AST and creatinine values were significantly higher in patients with delirium. We identified that the PEG rate was significantly low in patients who developed delirium. We thought that this result might have been be due to the decrease in delirium development through use of a PEG, which provides a partial reduction of nutritional problems in patients with stroke followed-up in palliative care.

Medications are an increasingly common precipitant of delirium as well as other neuropsychiatric adverse effects, especially in the elderly and other patients with altered pharmacokinetics and pharmacodynamics. ${ }^{[21]}$ Opioids, anticholinergics, anxiolytics, antipsychotics, antiepileptics and steroids are among the medications that most frequently cause delirium. ${ }^{[22]}$ Anticholinergic agents are commonly used for the treatment of several poststroke disorders including urinary bladder problems, spasticity, depression, and pain. The effects of medications on the development of delirium in stroke patients have previously been studied in a limited number of studies, and anticholinergics have been shown to increase the risk of delirium. ${ }^{[16,23]}$ In our study, we identified that the use of anticholinergics, narcotic analgesics, antiepileptics and antipsychotics was significantly high among patients with stroke who developed delirium, who had been under follow-up in our palliative care.

This study had several limitations: First, the patients included in the study had not been routinely screened for delirium; they had been accepted as delirium after evaluation by the psychiatry department. We think that some patients, particularly those who could have been diagnosed as hypoactive delirium during their clinical follow-up may have been omitted. Secondly, the etiology of delirium is multifactorial and has not been fully clarified. Location and size of the stroke lesion can be related to the risk of delirium; therefore, the lack of analysis of such a relationship is included in the limitations of this study.

\section{CONCLUSION}

Delirium is a complication that we commonly encounter, both in the acute period and during palliative care follow-up, in patients with stroke. In our study, we showed that age, infection, metabolic disorders and medications affected the development of delirium and the length of stay in palliative care in patients with stroke. We think that determining and managing the risk factors for delirium development in stroke patients followedup in palliative care will decrease the morbidity of the patients and improve their quality of life, and that further studies on this topic are needed. 


\section{ETHICAL DECLARATIONS}

Ethics Committee Approval: The study was carried out with the permission of Dr. Abdurrahman Yurtaslan Ankara Oncology Training and Research Hospital Ethics Committee (Date: 08.07.2020, Decision No:2020-07/682).

Informed Consent: Because the study was designed retrospectively, no written informed consent form was obtained from patients.

Referee Evaluation Process: Externally peer-reviewed.

Conflict of Interest Statement: The authors have no conflicts of interest to declare.

Financial Disclosure: The authors declared that this study has received no financial support.

Author Contributions: All of the authors declare that they have all participated in the design, execution, and analysis of the paper, and that they have approved the final version.

\section{REFERENCES}

1. American Psychiatric Association. Diagnostic and statistical manual of mental disorders, (Fifth Edition ed). Arlington:American Psychiatric Association, 2013.

2. Creutzfeldt CJ, Longstreth WT, Holloway RG. Predicting decline and survival in severe acute brain injury:the fourth trajectory. BMJ. 2015;351:h3904.

3. McManus J, Pathansali R, Stewart R, Macdonald A, Jackson S. Delirium Post-Stroke. Age Ageing. 2007;36(6):613-8.

4. Inouye SK, Westendorp RGJ, Saczynski JS. Delirium in Elderly People. Lancet. 2014;383(9920):911-22.

5. Holloway RG, Arnold RM, Creutzfeldt CJ, et al. Palliative and end-oflife care in stroke:a statement for healthcare professionals from the American Heart Association/American Stroke Association. Stroke. 2014;45:1887-916.

6. Holloway RG, Ladwig S, Robb J, Kelly A, Nielsen E, Quill TE. Palliative Care Consultations in Hospitalized Stroke Patients. J Palliat Med. 2010;13(4):407-412.

7. Eastman P, McCarthy G, Brand CA, Weir L, Gorelik A, Le B. Who, Why and When:Stroke Care Unit Patients Seen by a Palliative Care Service Within a Large Metropolitan Teaching Hospital. BMJ Support Palliat Care. 2013;3(1):77-83.

8. Patel MB, Bednarik J, Lee P, et al. Delirium Monitoring in Neurocritically III Patients:A Systematic Review. Critical care medicine. 2018;46(11):183241.

9. Naidech AM, Beaumont $\mathrm{JL}$, Rosenberg $\mathrm{NF}$, et al. Intracerebral hemorrhage and delirium symptoms. Length of stay, function, and quality of life in a 114-patient cohort. American journal of respiratory and critical care medicine. 2013;188(11):1331-7.

10. Hosie A, Davidson PM, Agar M, Sanderson CR, Phillips J. Delirium prevalence, incidence, and implications for screening in specialist palliative care inpatient settings:a systematic review. Palliat Med. 2013;27(6):486-98.

11. 11.Kim H, Chung S, Ho Joo Y, Lee JS. The major risk factors for delirium in a clinical setting. Neuropsychiatr Dis Treat. 2016;12:1787-93.

12. Shi Q, Warren L, Saposnik G, MacDermid JC. Confusion assessment method:a systematic review and meta-analysis of diagnostic accuracy. Neuropsychiatr Dis Treat. 2013;9:1359-70.

13. Langhorne $P$, Stott $D J$, Robertson $L$, et al. Medical complications after stroke:A multicenter study. Stroke. 2000;31(6):1223-29.

14. Vahidy FS, Bambhroliya AB, Meeks JR, et al. In-hospital outcomes and 30-day readmission rates among ischemic and hemorrhagic stroke patients with delirium. PLoS One. 2019;14(11):e0225204.
15. Simone MJ, Tan ZS. The Role of Inflammation in the Pathogenesis of Delirium and Dementia in Older Adults:A Review. CNS Neurosci Ther. 2011;17(5):506-13.

16. Caeiro L, Ferro JM, Claro MI. Delirium in acute stroke:a preliminary study of the role of anticholinergic medications. Eur J Neurol. 2004;11:699704.

17. McManus J, Pathansali $\mathrm{R}$, Hassan $\mathrm{H}$, et al. The course of delirium in acute stroke. Age and Aging. 2009;38:385-9

18. Nydahl P, Bartoszek $G$, Binder $A$, et al. Prevalence for delirium in stroke patients:A prospective controlled study. Brain Behav. 2017;7(8):e00748.

19. Khurana V, Gambhir IS, Kishore D. Evaluation of delirium in elderly:a hospital-based study. Geriatr Gerontol Int. 2011;11:467-73.

20. Kotfis K, Bott-Olejnik M, Szylińska A, Listewnik M, Rotter I. Characteristics, Risk Factors And Outcome Of Early-Onset Delirium In Elderly Patients With First Ever Acute Ischemic Stroke-A Prospective Observational Cohort Study. Clin Interv Aging. 2019;14:1771-82.

21. Bush SH, Tierney S, Lawlor PG. Clinical Assessment and Management of Delirium in the Palliative Care Setting. Drugs. 2017;77(15):1623-43.

22. Jackson N, Doherty J, Coulter S. Neuropsychiatric Complications of Commonly Used Palliative Care Drugs. Postgrad Med J. 2008;84(989):1216

23. Gustafson Y, Olsson T, Eriksson S, Asplund K, Bucht G. Acute confusional states (delirium) in stroke patients. Cerebrovasc Dis. 1991;1:257-64. 